\title{
The Implementation of Enterprise Business Intelligence: Case Study Approach
}

\author{
Min-Hooi Chuah and Kee-Luen Wong
}

Universiti Tunku Abdul Rahman, Perak, Malaysia

\begin{abstract}
Recently, Business Intelligence (BI) play an essential role particular in business areas. BI is particular important for enterprises and it enables manager to view business performance in convenient way and hence improve decision making. Despite knowing how important of BI implementation, many organizations still struggle to achieve this especially in the construction company. This paper proposes an Enterprise Business Maturity Model (EBI2M) and evaluates in the three construction company in Malaysia. Preliminary result indicates that that all three companies do not achieve highest maturity of BI implementation. Therefore, an EBI2M is used to provide symmetric guidelines for these companies to improve the BI implementation in the future.
\end{abstract}

Keywords: Business Intelligence, maturity model.

\section{Introduction}

BI applications have appeared the top spending priority for many Chief Information Officers (CIO) and it remain the most important technologies to be purchased for past five years(Gartner Research 2007; 2008; 2009). Although there has been a growing interest in BI area, success for implementing BI is still a questionable (Ang \& Teo 2000; Lupu et.al (1997); Computerworld (2003)). Lupu et.al (1997) reported that about 60\%$70 \%$ of business intelligence applications fail due to the technology, organizational, cultural and infrastructure issues. Furthermore, EMC Corporation argued that many BI initiatives have failed because tools weren't accessible through to end users and the result of not meeting the end users' need effectively. Computerworld (2003) stated that BI projects fail because of failure to recognize BI projects as cross organizational business initiatives, unengaged business sponsors, unavailable or unwilling business representatives, lack of skilled and available staff, no business analysis activities, no appreciation of the impact of dirty data on business profitability and no understanding of the necessity for and the use of meta-data. A maturity model is needed to provide systematic maturity guidelines and readiness assessment for such resourceful initiative. While there are many BI maturity models in the literature but most of them do not consider all factors affecting on BI. Some of BI maturity models focus on the technical aspect and some of the models focus on business point of view.

Therefore, this research seeks to bridge this missing gap between academia and industry, through a thorough formal study of the key dimensions and associated factors pertaining to Enterprise Business Intelligence (EBI). It aims to investigate the dimensions and associated factor for each maturity level. The remainder of this paper has been structured as follows. The next section discusses the components of Business Intelligence (BI), Capability Maturity Model (CMMI) as well as review of BI maturity models. The third section then outlines and discusses the

Copyright (C) 2013 Min-Hooi Chuah and Kee-Luen Wong. This is an open access article distributed under the Creative Commons Attribution License unported 3.0, which permits unrestricted use, distribution, and reproduction in any medium, provided that original work is properly cited. Contact author: Min-Hooi Chuah Email: chuahmh@utar.edu.my 
proposed EBIM model, then follows by empirical research.

\section{Literature Review}

There are many Business Intelligence maturity model developed by different authors such as Business intelligence Development Model (BIDM), TDWI's maturity model, Business Intelligence
Maturity Hierarchy, Hewlett Package Business Intelligence Maturity Model, Gartner's Maturity Model, Business Information Maturity Model, AMR Research's Business Intelligence/ Performance Management Maturity Model, Infrastructure Optimization Maturity Model and Ladder of business intelligence (LOBI). This section reviewed several of business intelligence maturity models by different authors.

Table 1: Summary of Various BI Maturity Models

\begin{tabular}{|c|c|}
\hline Maturity models & Description \\
\hline TDWI's maturity model & $\begin{array}{l}\text { - The maturity assessment tool is } \\
\text { available in the web to evaluate BI's maturity } \\
\text { level as well as documentation. } \\
\text { - Concentrates on the technical } \\
\text { viewpoints especially in data warehouse aspect. } \\
\text { - Can be improved on business viewpoint } \\
\text { especially from the cultural and organizational } \\
\text { view. }\end{array}$ \\
\hline $\begin{array}{l}\text { Business Intelligence Maturity } \\
\text { Hierarchy }\end{array}$ & $\begin{array}{l}\text { - Applied the knowledge management } \\
\text { field } \\
\text { - Author constructed maturity levels from } \\
\text { a technical point of view but can considered as } \\
\text { incomplete. } \\
\text { - The documentation of this model in the } \\
\text { form of one paper and is not enough for maturity } \\
\text { level assessment. }\end{array}$ \\
\hline $\begin{array}{l}\text { Hewlett Package Business } \\
\text { Intelligence Maturity Model }\end{array}$ & $\begin{array}{l}\text { Depicts the maturity levels from } \\
\text { business technical aspect. } \\
\text { - } \quad \text { This model is new and need to improve } \\
\text { to add more technical aspects such as data- } \\
\text { warehousing and analytical aspects. }\end{array}$ \\
\hline Gartner's Maturity Model & $\begin{array}{l}\text { - Uses to evaluate the business maturity } \\
\text { levels and maturity of individual departments. } \\
\text { - } \quad \text { Provides more non technical view and } \\
\text { concentrates on the business technical aspect. } \\
\text { - Well documented and can search easily } \\
\text { on the Web. } \\
\text { The assessment offers the series of } \\
\text { questionnaire to form of spreadsheet. }\end{array}$ \\
\hline $\begin{array}{l}\text { Business Information Maturity } \\
\text { Model }\end{array}$ & $\begin{array}{l}\text { Well documented with the series of } \\
\text { questionnaire to assist the users to perform self } \\
\text { evaluation. } \\
\text { - However, criteria to evaluate the } \\
\text { maturity level are not well defined. }\end{array}$ \\
\hline $\begin{array}{l}\text { AMR Research's Business } \\
\text { Intelligence/ Performance }\end{array}$ & $\begin{array}{l}\text { - Concentrates on the performance } \\
\text { management and balanced scorecard rather than }\end{array}$ \\
\hline
\end{tabular}




\begin{tabular}{|c|c|}
\hline Management Maturity Model & $\begin{array}{l}\text { business intelligence. } \\
\text { - Not well documented and criteria to } \\
\text { evaluate the maturity level are not well defined. } \\
\text { - No questionnaire to evaluate the } \\
\text { maturity levels and is very hard to analysis the } \\
\text { model }\end{array}$ \\
\hline $\begin{array}{l}\text { Infrastructure Optimization } \\
\text { Maturity Model }\end{array}$ & $\begin{array}{l}\text { - Focuses on the measurement of the } \\
\text { efficiency of reporting, analysis and data- } \\
\text { warehousing and is not complete in the business } \\
\text { intelligence area } \\
\text { - } \quad \text { Discuss about the products and } \\
\text { technologies rather than business point of view } \\
\text { - Not well documented and criteria to } \\
\text { evaluate the maturity level are not well defined. }\end{array}$ \\
\hline $\begin{array}{l}\text { Ladder of business intelligence } \\
\text { (LOBI) }\end{array}$ & $\begin{array}{l}\text { - Apply the knowledge management field } \\
\text { - } \quad \text { Author constructed maturity levels from } \\
\text { a technical point of view but can considered as } \\
\text { incomplete. } \\
\text { - } \quad \text { Not well documented and criteria to } \\
\text { evaluate the maturity level are not well defined. }\end{array}$ \\
\hline $\begin{array}{l}\text { Business intelligence } \\
\text { Development Model (BIDM) }\end{array}$ & $\begin{array}{l}\text { - Not well documented and criteria to } \\
\text { evaluate the maturity level are not well defined. } \\
\text { - Concentrates on the technical aspects } \\
\text { rather than business point of view }\end{array}$ \\
\hline
\end{tabular}

Table 1 above depicts summary of various business intelligence maturity models. As shown in the table 1 , the majority of the models do not focus the business intelligence as entire which some of models focus on the technical aspect and some of the models focus on business point of view. For example, TDWI's model only concentrates on the data warehousing while Business Intelligence Maturity Hierarchy only concentrates on knowledge management. It is not complete to represent business intelligence. We know that business intelligence covers not only data warehousing, but also business performance, balanced scorecard, analytical components. In addition, the documentation of some maturity models above is not well defined and they do not provide any guidelines or questionnaire to evaluate maturity levels.

\section{Proposed Framework}

Based on the literature review above, the majority of the models do not focus the business intelligence as entire which some of models focus on the technical aspect and some of the models focus on business point of view. If the organizations want to know exact their business intelligence maturity levels as whole, they have to use multiple models and that it is time consuming. Hence, there is need to have integrated maturity model to combine existing different maturity model and questionnaires and evaluation criteria should be provided. In view of this, an Enterprise Business Intelligence Maturity Model (EBI2M) is proposed.

The proposed EBI2M consists of five levels namely; initial, managed, defined, 
quantitatively managed and optimizing; all of which are adapted from CMMI maturity levels. There are thirteen key process areas, namely; change management, culture, strategic management, process, people, performance management, balanced scorecard, information quality, data warehousing, master data management, analytical, infrastructure and knowledge management.

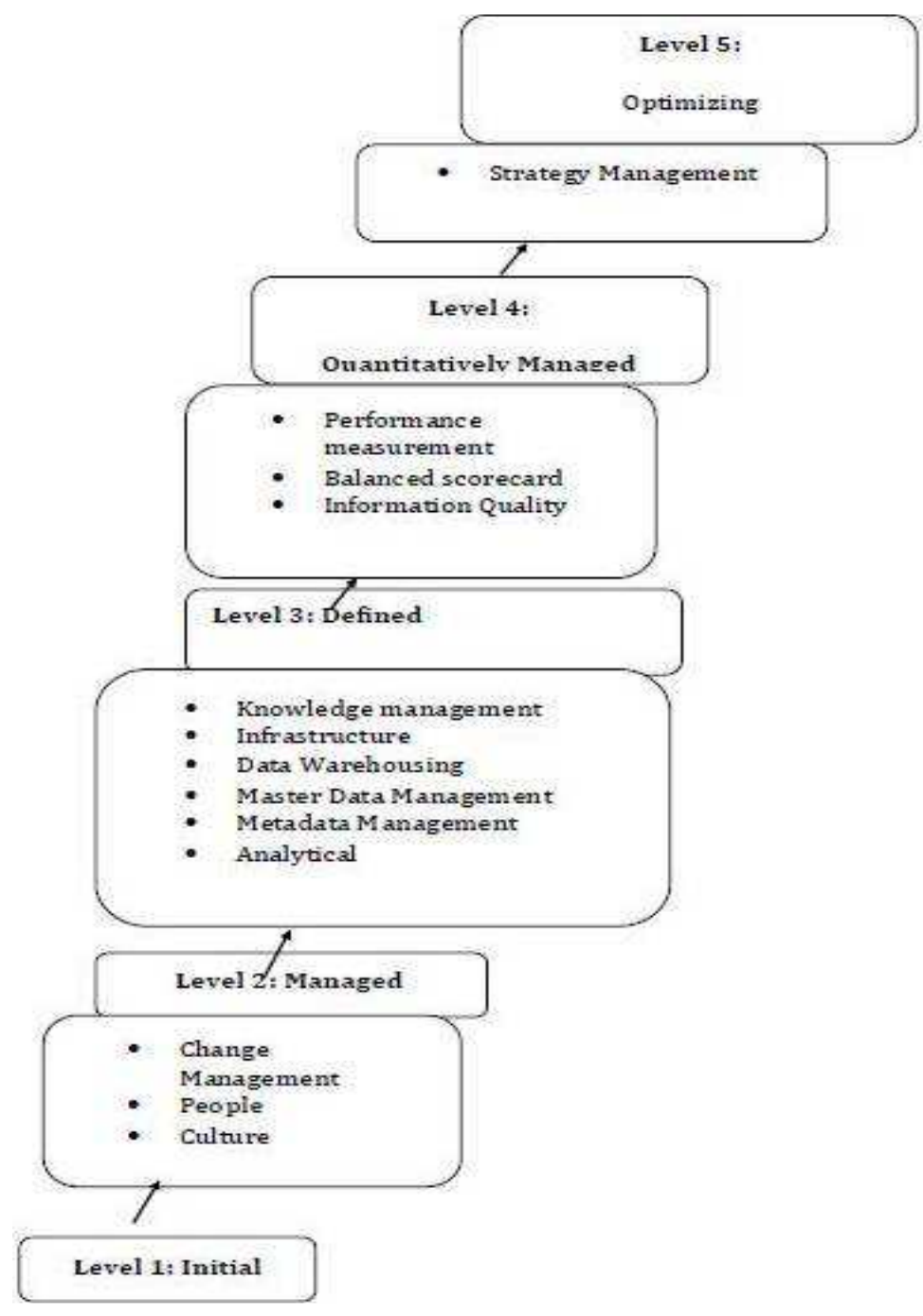

Figure 1: Preliminary Enterprise Business Intelligence Maturity Model (EBI2M) Developed by Author

\section{Methodology}

The proposed Enterprise Business Intelligence Maturity model (EBI2M) was applied in the three construction companies in order to evaluate the maturity of $\mathrm{BI}$ implementation. This case study was prepared following a series of detailed interviews with staff, the collection of supporting documents and follow up interviews to clarify specific issues arising from the analysis of case study materials. 
Table 2: Case Study's Participate

\begin{tabular}{|c|l|l|c|c|}
\hline Company & \multicolumn{1}{|c|}{ Industry } & \multicolumn{1}{|c|}{$\begin{array}{c}\text { Positions of } \\
\text { Interviewers }\end{array}$} & $\begin{array}{c}\text { Size of } \\
\text { employees }\end{array}$ & $\begin{array}{c}\text { Years of } \\
\text { experiences in BI }\end{array}$ \\
\hline A & $\begin{array}{c}\text { Construction and } \\
\text { property }\end{array}$ & $\begin{array}{l}\text { Executive vice } \\
\text { president (strategic } \\
\text { planning) }\end{array}$ & $\begin{array}{c}\mathbf{1 0 0 0} \text { to } \\
\mathbf{5 0 0 0}\end{array}$ & $\mathbf{5 - 6}$ years \\
\hline B & $\begin{array}{l}\text { Construction and } \\
\text { property }\end{array}$ & CIO and MIS mangers & 1000 to 5000 & $1-2$ years \\
\hline C & $\begin{array}{l}\text { Construction and } \\
\text { property, } \\
\text { Healthcare, } \\
\text { education }\end{array}$ & CIO and IT mangers & $\begin{array}{c}\text { Above } \\
10,000\end{array}$ & $1-2$ years \\
\hline
\end{tabular}

\section{Results and Discussions}

The respondents were instructed to rate their companies' capabilities of BI implementation from level 0-5.

Data Warehouse Perspective
Below are the results of three companies' capabilities of BI implementation on thirteen dimensions.

Table 3: Data Warehouse Perspective

\begin{tabular}{|c|c|c|c|c|c|}
\hline $\begin{array}{l}\text { Key process } \\
\text { area }\end{array}$ & Criteria & Appraisal Measures & $\begin{array}{c}\text { Company } \\
\text { A }\end{array}$ & $\begin{array}{c}\text { Company } \\
\text { B }\end{array}$ & Company C \\
\hline \multirow[t]{4}{*}{$\begin{array}{l}\text { Data } \\
\text { Warehouse }\end{array}$} & \multirow[t]{3}{*}{ ETL } & $\begin{array}{l}\text { Ability to read directly from } \\
\text { your data source }\end{array}$ & 3 & 1 & 3 \\
\hline & & $\begin{array}{l}\text { Automating capturing and } \\
\text { delivery of metadata }\end{array}$ & 1 & 0 & 3 \\
\hline & & $\begin{array}{l}\text { An easy to use interface for } \\
\text { the developer and the functional }\end{array}$ & 3 & 1 & 3 \\
\hline & Data Mart & No redundancy of data mart & 4 & 0 & 3 \\
\hline
\end{tabular}

Table 3 depicts the capabilities levels among three companies in data warehouse perspective. As shown in table 3, Company B has lowest capacities in term of ETL and data marts. This is might be due to lack of top management support and lack of experience among IT developers in the company B. 


\section{Master Data Management (MDM) Perspective}

Table 4: Master Data Management (MDM) Perspective

\begin{tabular}{|c|c|c|c|c|c|}
\hline $\begin{array}{l}\text { Key process } \\
\text { area }\end{array}$ & Criteria & Appraisal Measures & $\begin{array}{c}\text { Company } \\
\text { A }\end{array}$ & $\begin{array}{c}\text { Company } \\
\text { B }\end{array}$ & Company \\
\hline \multirow[t]{8}{*}{$\begin{array}{l}\text { Master Data } \\
\text { Management } \\
(\text { MDM) }\end{array}$} & \multirow[t]{3}{*}{$\begin{array}{l}\text { Data } \\
\text { Integration and } \\
\text { Synchronization }\end{array}$} & $\begin{array}{l}\text { Combining data residing in } \\
\text { different sources and providing users } \\
\text { with a unified view of these data }\end{array}$ & 2 & 1 & 3 \\
\hline & & $\begin{array}{l}\text { Establishing consistency } \\
\text { among data from a source to a target } \\
\text { data storage and vice versa and the } \\
\text { continuous harmonization of the data } \\
\text { over time }\end{array}$ & 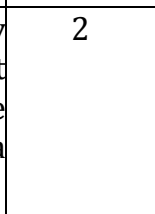 & 2 & 3 \\
\hline & & $\begin{array}{l}\text { Ensuring multiple versions of } \\
\text { a data are synchronized }\end{array}$ & 2 & 2 & 3 \\
\hline & \multirow[t]{2}{*}{ Data Profiling } & $\begin{array}{l}\text { Ability to find out whether } \\
\text { existing data can easily be used for } \\
\text { other purposes }\end{array}$ & 2 & 2 & 3 \\
\hline & & $\begin{array}{l}\text { The ability to search the data } \\
\text { by tagging it with keywords, } \\
\text { descriptions, or assigning it to a } \\
\text { category }\end{array}$ & 3 & 0 & 3 \\
\hline & \multirow[t]{2}{*}{ Data Migration } & $\begin{array}{l}\text { Ability of data on the old } \\
\text { system is mapped to the new system }\end{array}$ & 2 & 3 & 3 \\
\hline & & $\begin{array}{l}\text { Ability of data move from } \\
\text { disk files from one folder (or computer) } \\
\text { to another }\end{array}$ & 2 & 3 & 3 \\
\hline & $\begin{array}{l}\text { Data } \\
\text { Consolidation } \\
\text { Segmentation }\end{array}$ & $\begin{array}{l}\text { Ability to collect master data } \\
\text { from several systems at a central } \\
\text { location and groups of individuals that } \\
\text { are similar in specific ways relevant into } \\
\text { several categories such as age }\end{array}$ & 3 & 1 & 3 \\
\hline
\end{tabular}

Table 4 depicts the capabilities levels among three companies in master data management perspective. The overall score for company A,
$B$ and $C$ is $3.13,1.67$ and 3 respectively. Company $\mathrm{B}$ is lowest capacities among company A and B. 
Metadata Management Perspective

Table 5: Metadata Management Perspective

\begin{tabular}{|c|c|c|c|c|c|}
\hline $\begin{array}{c}\text { Key process } \\
\text { area }\end{array}$ & Criteria & Appraisal Measures & \begin{tabular}{|c|} 
Company \\
$\mathbf{A}$ \\
\end{tabular} & \begin{tabular}{|c|} 
Company \\
B \\
\end{tabular} & $\begin{array}{c}\text { Company } \\
\text { C }\end{array}$ \\
\hline \multirow[t]{3}{*}{$\begin{array}{l}\text { 3Metadata } \\
\text { M3anagement }\end{array}$} & $\begin{array}{l}\text { Business } \\
\text { Metadata }\end{array}$ & $\begin{array}{l}\text { Ability to define business } \\
\text { rule for manipulating, transforming, } \\
\text { calculating and summarizing }\end{array}$ & 2 & 1 & 3 \\
\hline & $\begin{array}{l}\text { Technical } \\
\text { Metadata }\end{array}$ & $\begin{array}{l}\text { Ability to provide } \\
\text { information regarding configuration, } \\
\text { tools and programs }\end{array}$ & 2 & 1 & 3 \\
\hline & $\begin{array}{l}\text { Operational } \\
\text { Metadata }\end{array}$ & $\begin{array}{l}\text { Ability to provide } \\
\text { information regarding change and } \\
\text { update activity, archiving, backup and } \\
\text { usage statistics }\end{array}$ & 2 & 1 & 3 \\
\hline
\end{tabular}

Table 5 depicts the capabilities levels among three companies in metadata management perspective. The overall score for company A,
$\mathrm{B}$ and $\mathrm{C}$ is 2,1 and 3 respectively. Company $\mathrm{B}$ is lowest capacities among company $\mathrm{A}$ and $\mathrm{B}$.

\section{Knowledge Management Perspective}

Table 6: Knowledge Management Perspective

\begin{tabular}{|c|c|c|c|c|c|}
\hline $\begin{array}{l}\text { Key process } \\
\text { area }\end{array}$ & Criteria & Appraisal Measures & $\begin{array}{c}\text { Company } \\
\text { A }\end{array}$ & $\begin{array}{c}\text { Company } \\
\text { B }\end{array}$ & $\begin{array}{c}\text { Company } \\
\text { C }\end{array}$ \\
\hline \multirow[t]{4}{*}{$\begin{array}{l}\text { Knowledge } \\
\text { management }\end{array}$} & $\begin{array}{l}\text { Knowledge } \\
\text { creation }\end{array}$ & $\begin{array}{l}\text { Knowledge can be created } \\
\text { through the way of people's doing things } \\
\text { or developing something }\end{array}$ & 2 & 1 & 3 \\
\hline & $\begin{array}{l}\text { Knowledge } \\
\text { Capturing }\end{array}$ & $\begin{array}{l}\text { New knowledge should } \\
\text { identified and represented in a } \\
\text { convenient way }\end{array}$ & 2 & 2 & 3 \\
\hline & $\begin{array}{l}\text { Knowledge } \\
\text { Refining }\end{array}$ & $\begin{array}{l}\text { Knowledge must be put in } \\
\text { context so that it is actionable. }\end{array}$ & 2 & 2 & 3 \\
\hline & $\begin{array}{l}\text { Knowledge } \\
\text { Storing }\end{array}$ & $\begin{array}{l}\text { Knowledge must stored in a } \\
\text { knowledge repository to let } \\
\text { organization access it }\end{array}$ & 2 & 0 & 3 \\
\hline
\end{tabular}

Table 6 depicts the capabilities levels among three companies in knowledge management perspective. The overall score for company A, $B$ and $C$ is 2, 1.25 and 3 respectively.
Company B is lowest capacities among company A and B in knowledge management perspective. 
Infrastructure Perspective

Table 7: Infrastructure Perspective

\begin{tabular}{|l|l|l|c|c|c|}
\hline $\begin{array}{l}\text { Key process } \\
\text { area }\end{array}$ & Criteria & Appraisal Measures & $\begin{array}{c}\text { Company } \\
\text { A }\end{array}$ & $\begin{array}{c}\text { Company } \\
\text { B }\end{array}$ & $\begin{array}{c}\text { Company } \\
\text { C }\end{array}$ \\
\hline Infrastructure & Networking & $\begin{array}{c}\text { Centralized and } \\
\text { enterprise levels }\end{array}$ & 3 & 3 & 3 \\
\hline
\end{tabular}

Table 7 depicts the capabilities levels among three companies in infrastructure perspective. Company A, B and C has achieved capacities of score of 3 .

\section{Analytical Perspective}

\section{Table 8: Analytical Perspective}

\begin{tabular}{|c|c|c|c|c|c|}
\hline $\begin{array}{l}\text { Key process } \\
\text { area }\end{array}$ & Criteria & Appraisal Measures & $\begin{array}{c}\text { Company } \\
\text { A }\end{array}$ & $\begin{array}{c}\text { Company } \\
\text { B }\end{array}$ & $\begin{array}{c}\text { Company } \\
\text { C }\end{array}$ \\
\hline \multirow[t]{4}{*}{ Analytical } & \multirow[t]{4}{*}{ OLAP } & $\begin{array}{l}\text { - } \\
\text { reporting (develity to support Ad hoc } \\
\end{array}$ & 3 & 1 & 1 \\
\hline & & \begin{tabular}{|l} 
- Ability to support historical \\
comparisons/trending
\end{tabular} & 3 & 1 & 3 \\
\hline & & $\begin{array}{l}\text { Ability to perform drill down } \\
\text { back to the source Data Base tables }\end{array}$ & 2 & 1 & 2 \\
\hline & & $\begin{array}{l}\text { - Ability to do ad hoc complex } \\
\text { calculations (@ report level and cube } \\
\text { level) }\end{array}$ & 3 & 0 & 3 \\
\hline
\end{tabular}

Table 8 depicts the capabilities levels among three companies in analytical perspective. The overall score for company A, B and C is
$2.75,0.75$ and 2.25 respectively. Company B is lowest capacities among company A and B in analytical perspective. 
9 Journal of Southeast Asian Research

Performance Measurement Perspective

Table 9: Performance Measurement Perspective

\begin{tabular}{|c|c|c|c|c|c|}
\hline $\begin{array}{l}\text { Key process } \\
\text { area }\end{array}$ & Criteria & Appraisal Measures & $\begin{array}{c}\text { Company } \\
\text { A }\end{array}$ & $\begin{array}{c}\text { Company } \\
\text { B }\end{array}$ & $\begin{array}{c}\text { Company } \\
\text { C }\end{array}$ \\
\hline \multirow[t]{5}{*}{$\begin{array}{l}\text { Performance } \\
\text { measurement }\end{array}$} & $\begin{array}{l}\text { Scope of } \\
\text { Measurement }\end{array}$ & $\begin{array}{l}\text { - Financial and } \\
\text { non-financial indicators } \\
\text { are measured on a } \\
\text { regular basis. }\end{array}$ & 3 & 3 & 5 \\
\hline & Data collection & $\begin{array}{l}\text { Collection of } \\
\text { financial and non } \\
\text { financial performance } \\
\text { data is fully automated. }\end{array}$ & 3 & 1 & 3 \\
\hline & Storage of data & $\begin{array}{l}\text { Performance } \\
\text { data is stored in an } \\
\text { integrated IT system. }\end{array}$ & 3 & 0 & 3 \\
\hline & $\begin{array}{l}\text { Communication of } \\
\text { performance } \\
\text { results }\end{array}$ & \begin{tabular}{|l} 
Financial and \\
non-financial \\
performance \\
results are
\end{tabular} & 2 & 0 & 4 \\
\hline & $\begin{array}{l}\text { Use of the } \\
\text { measurement }\end{array}$ & $\begin{array}{l}\text { Quantitative } \\
\text { goals for the } \\
\text { measurement processes } \\
\text { are set. }\end{array}$ & 2 & 1 & 5 \\
\hline
\end{tabular}

Table 9 depicts the capabilities levels among three companies in performance measurement perspective. The overall score for company $\mathrm{A}, \mathrm{B}$ and $\mathrm{C}$ is 2.6, 1 and 4 respectively. Company $\mathrm{B}$ is lowest capacities among company $\mathrm{A}$ and $\mathrm{B}$ in performance measurement perspective. 
Balanced Scorecard Perspective

Table 10: Balanced Scorecard Perspective

\begin{tabular}{|l|l|l|c|c|c|}
\hline $\begin{array}{c}\text { Key process } \\
\text { area }\end{array}$ & \multicolumn{1}{|c|}{ Criteria } & \multicolumn{1}{c|}{ Appraisal Measures } & $\begin{array}{c}\text { Company } \\
\text { A }\end{array}$ & $\begin{array}{c}\text { Company } \\
\text { B }\end{array}$ & $\begin{array}{c}\text { Company } \\
\text { C }\end{array}$ \\
\hline $\begin{array}{l}\text { Balanced } \\
\text { Scorecard }\end{array}$ & Financial & $\begin{array}{l}\text { Ability to answer to the } \\
\text { question "How do we look to } \\
\text { shareholders?" }\end{array}$ & 1 & 3 & 5 \\
\cline { 2 - 6 } & Customer & $\begin{array}{l}\text { Ability to answer the } \\
\text { question "How do customers see } \\
\text { us?" }\end{array}$ & 1 & 3 & 5 \\
\cline { 2 - 7 } & $\begin{array}{lll}\text { Internal Business } \\
\text { Processes }\end{array}$ & $\begin{array}{l}\text { Ability to answer the } \\
\text { question "What must we excel at?" }\end{array}$ & 3 & 3 & 5 \\
\cline { 2 - 7 } & $\begin{array}{l}\text { Learning and } \\
\text { Growth }\end{array}$ & $\begin{array}{l}\text { Ability to answer } \\
\text { questions "Can we continue to } \\
\text { improve and create value? }\end{array}$ & 2 & 3 & 5 \\
\hline
\end{tabular}

Table 10 depicts the capabilities levels among three companies in balanced scorecard perspective. The overall score for company A, B and $\mathrm{C}$ is $1.75,3$ and 5 respectively. Company A is lowest capacities among company $\mathrm{B}$ and $\mathrm{C}$ in balanced scorecard perspective.

\section{Information Quality (IQ) Perspective}

Table 11: Information Quality Perspective

\begin{tabular}{|c|c|c|c|c|c|}
\hline $\begin{array}{l}\text { Key process } \\
\text { area }\end{array}$ & Criteria & Appraisal Measures & $\begin{array}{c}\text { Company } \\
\text { A }\end{array}$ & $\begin{array}{c}\text { Company } \\
\text { B }\end{array}$ & Company \\
\hline \multirow[t]{5}{*}{$\begin{array}{l}\text { Information } \\
\text { Quality }\end{array}$} & Accuracy & $\begin{array}{l}\text { The degree to which } \\
\text { data value agree with an } \\
\text { identified source of correct } \\
\text { information }\end{array}$ & 3 & 2 & 3 \\
\hline & Completeness & $\begin{array}{l}\text { The expectation that } \\
\text { data instances contain all the } \\
\text { information they are supposed to. }\end{array}$ & 3 & 1 & 3 \\
\hline & Consistency & $\begin{array}{l}\text { The degree to which } \\
\text { information is in the same format }\end{array}$ & 3 & 2 & 3 \\
\hline & \multirow[t]{2}{*}{ Timeliness } & $\begin{array}{l}\text { The degree to which } \\
\text { information is current with the } \\
\text { world that it models }\end{array}$ & 2 & 3 & 3 \\
\hline & & data $\quad$ How up to date is the & 3 & 2 & 3 \\
\hline
\end{tabular}


Table 11 depicts the capabilities levels among three companies in information quality perspective. The overall score for company A, B and $\mathrm{C}$ is 2.88, 1.88 and 3 respectively. Company B is lowest capacities among company $\mathrm{A}$ and $\mathrm{C}$ in information quality perspective.

\section{People Perspective}

Table 12: People Perspective

\begin{tabular}{|c|c|c|c|c|c|}
\hline \multirow{3}{*}{\begin{tabular}{|l|} 
Key process \\
area \\
People
\end{tabular}} & \multirow{3}{*}{\begin{tabular}{|l|} 
Criteria \\
Leadership
\end{tabular}} & \multirow[t]{2}{*}{ Appraisal Measures } & \multicolumn{2}{|c|}{ Company Company } & \multirow{2}{*}{\begin{tabular}{|c|} 
Company \\
C \\
\end{tabular}} \\
\hline & & & $\mathbf{A}$ & B & \\
\hline & & $\begin{array}{l}\text { Pro-active in preparing } \\
\text { the organization for the future }\end{array}$ & 4 & 3 & 4 \\
\hline & & $\begin{array}{l}\text { Visible and engaged to } \\
\text { ensure that staff understand the } \\
\text { common vision and can translate it } \\
\text { into terms relevant to their roles }\end{array}$ & 4 & 2 & 4 \\
\hline & Skills & $\begin{array}{l}\text { Seeks to recruit people } \\
\text { with good information skills and } \\
\text { the workforce contains a high } \\
\text { percentage of knowledge workers }\end{array}$ & 4 & 2 & 5 \\
\hline & Training & $\begin{array}{l}\text { Comprehensive training } \\
\text { plan program are scheduled } \\
\text { and organized. }\end{array}$ & 4 & 2 & 5 \\
\hline & Dynamic & $\begin{array}{l}\text { Multidisciplinary team / } \\
\text { cross functional peers group } \\
\text { come together to solve corporate } \\
\text { issues. }\end{array}$ & 4 & 3 & 4 \\
\hline
\end{tabular}

Table 12 depicts the capabilities levels among three companies in people perspective. The overall score for company A,
$\mathrm{B}$ and $\mathrm{C}$ is 4, 4.38 and 4.5 respectively. Company $\mathrm{A}$ is lowest capacities among company $\mathrm{B}$ and $\mathrm{C}$ in people perspective.

\section{Organization Culture Perspective}

\section{Table 13: Organization Culture Perspective}

\begin{tabular}{|l|l|l|c|c|c|}
\hline $\begin{array}{l}\text { Key process } \\
\text { area }\end{array}$ & Criteria & Appraisal Measures & $\begin{array}{c}\text { Company } \\
\text { A }\end{array}$ & $\begin{array}{c}\text { Company } \\
\text { B }\end{array}$ & $\begin{array}{c}\text { Company } \\
\text { C }\end{array}$ \\
\hline $\begin{array}{l}\text { Organization } \\
\text { Culture }\end{array}$ & Reward & $\begin{array}{l}\text { The compensation structure } \\
\text { rewards knowledge workers with high } \\
\text { analytical skills and collaborative ability. }\end{array}$ & 4 & 3 & 4 \\
\cline { 2 - 6 } & Attitude & $\begin{array}{l}\text { The environment of companies } \\
\text { is not competitive. }\end{array}$ & 3 & 3 & 4 \\
\cline { 3 - 6 } & $\begin{array}{l}\text { People are starting to think } \\
\text { strategically and a lot of ideas are being } \\
\text { generated }\end{array}$ & 4 & 3 & 4 \\
\hline
\end{tabular}


Table 13 depicts the capabilities levels among three companies in organization culture perspective. The overall score for company $\mathrm{A}, \mathrm{B}$ and $\mathrm{C}$ is $3.75,3$ and 4 respectively. Company B is lowest capacities among company $\mathrm{A}$ and $\mathrm{C}$ in organization culture perspective.

\section{Strategic Management Perspective}

Table 14: Company A's Strategic Management Perspective

\begin{tabular}{|c|c|c|c|c|c|}
\hline $\begin{array}{l}\text { Key process } \\
\text { area }\end{array}$ & Criteria & Appraisal Measures & $\begin{array}{c}\text { Company } \\
\text { A }\end{array}$ & $\begin{array}{c}\text { Company } \\
\text { B }\end{array}$ & $\begin{array}{c}\text { Company } \\
\text { C }\end{array}$ \\
\hline \multirow[t]{6}{*}{$\begin{array}{l}\text { Strategic } \\
\text { management }\end{array}$} & \multirow[t]{4}{*}{$\begin{array}{l}\text { Strategic } \\
\text { thinking and } \\
\text { planning }\end{array}$} & $\begin{array}{l}\text { Ability to use consistent } \\
\text { definitions of planning terms and } \\
\text { to understand their distinctions }\end{array}$ & 3 & 3 & 4 \\
\hline & & $\begin{array}{l}\text { Awareness of the } \\
\text { distinctions between project } \\
\text { planning and strategic planning }\end{array}$ & 4 & 3 & 4 \\
\hline & & $\begin{array}{l}\text { Ability to discuss and } \\
\text { describe items in plans at the } \\
\text { appropriate "strategic altitude" }\end{array}$ & 4 & 3 & 4 \\
\hline & & $\begin{array}{l}\text { Awareness of the } \\
\text { dynamic system effects in } \\
\text { organizations, such as delays and } \\
\text { feedback }\end{array}$ & 4 & 3 & 4 \\
\hline & Visions & $\begin{array}{l}\text { People at all levels are } \\
\text { motivated by a common vision } \\
\text { and strategy }\end{array}$ & 4 & 3 & 4 \\
\hline & Goals & 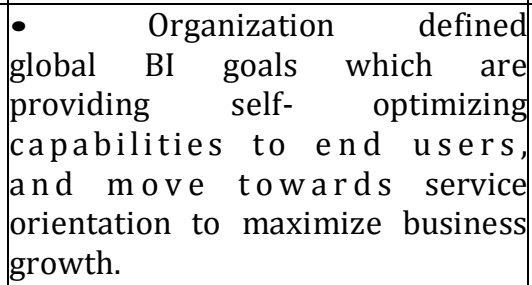 & | & 2 & 1 \\
\hline
\end{tabular}

Table 14 depicts the capabilities levels among three companies in organization culture perspective. The overall score for company $\mathrm{A}, \mathrm{B}$ and $\mathrm{C}$ is $3.58,2.67$ and 3 respectively. Company B is lowest capacities among company $\mathrm{A}$ and $\mathrm{C}$ in organization culture perspective. 
Change Management Perspective

Table 15: Company A's Change Management Perspective

\begin{tabular}{|l|c|c|c|c|c|}
\hline $\begin{array}{l}\text { Key process } \\
\text { area }\end{array}$ & Criteria & Appraisal Measures & $\begin{array}{c}\text { Company } \\
\text { A }\end{array}$ & $\begin{array}{c}\text { Company } \\
\text { B }\end{array}$ & $\begin{array}{c}\text { Company } \\
\text { C }\end{array}$ \\
\hline $\begin{array}{l}\text { Change } \\
\text { Management }\end{array}$ & Adaptability & $\begin{array}{l}\text { Employees across the } \\
\text { enterprise understand change } \\
\text { management, why it is important to } \\
\text { project success and how they play a } \\
\text { role in making change successful. }\end{array}$ & 4 & 1 & 4 \\
\cline { 2 - 5 } & $\begin{array}{l}\text { Employees can adapt to } \\
\text { the change }\end{array}$ & 4 & 2 & 3 \\
\hline
\end{tabular}

Table 15 depicts the capabilities levels among three companies in change management culture perspective. The overall score for company A, B and C is 4, 1.5 and 3.5 respectively. Company $\mathrm{B}$ is lowest capacities among company $\mathrm{A}$ and $\mathrm{C}$ in change management perspective.

\section{Conclusions}

This paper proposes an EBI maturity model (EBI2M) to help the firms to identify the existing problems of BI implementation and plan a systematic path to evolve to higher levels of maturity. An EBI2M is evaluated through three companies in construction area. The result indicates that all three companies do not achieve highest maturity of BI implementation. Therefore, an EBI2M is used to provide symmetric guidelines for these companies to improve the $\mathrm{BI}$ implementation in the future.

\section{Acknowledgment}

The authors acknowledge the time and commitment of all participants in the case study.

\section{References}

Ang, J .\& Teo, T. S. H. (2000). "Management Issues in Data Warehousing: Insights from the Housing and Development Board," Decision Support Systems. 29(1): 11-20.
Carlo, V. (2009). 'Business Intelligence: Data Mining and Optimization for Decision Making,' Wiley.

Cates, J. E., Gill, S. S. \& Zeituny, N. (2005). "The Ladder of Business Intelligence (LOBI): A Framework for Enterprise IT Planning and Architecture," International Journal of Business Information system. 1(1): 220-238.

Chang, E. (2006). “Advanced BI Technologies, Trust, Reputation and Recommendation Systems," 7th Business Intelligence Conference (Organised by Marcus Evans), Sydney, Australia.

Computerworld (2003). "The Top 10 Critical Challenges for Business Intelligence Success," Computerworld.

Deng, R. (2007). "Business Intelligence Maturity Hierarchy: A New Perspective from Knowledge Management," Information Management. http://www.informationmanagement.com/ infodirect/20070323/1079089-1.html

Eckerson, W. (2004). "Gauge Your Data Warehouse Maturity," Information management. viewed on 29. April 2009, <http://www.informationmanagement.com/issues/20041101/101239 1-1.html>. 
Faherty, V. (1979). "Continuing Social Work Education: Results of a Delphi Surved," Journal of Education for Social Work. 15(1): 12-19.

Gartner Research (2007). Gartner EXP Survey of More than 1,400 CIOs Shows CIOs Must Create Leverage to Remain Relevant to the Business, Retrieved 01/04/2009, from <http://www.gartner.com/it/page.jsp?id=50 1189>.

Gartner Research (2008). Gartner EXP Worldwide Survey of 1,500 CIOs Shows 85 Percent of CIOs Expect Significant Change over Next Three Years, Retrieved 01/04/2009, from <http://www.gartner.com/it/page.jsp?id=58 7309>.

Gartner Research (2009). Gartner EXP Worldwide Survey of More than 1,500 CIOs Shows IT Spending to Be Flat in 2009, Retrieved 01/04/2009, from <http://www.gartner.com/it/page.jsp?id=85 5612>.

Hagerty, J. (2006). “AMR Research's Business Intelligence/ Performance Management Maturity Model, Version 2," Viewed on 21 April 2009 , <http://www.cognos.com/pdfs/analystrepor ts/ar_amr_researchs_bi_perf.pdf

Hewlett-Packard (2007). 'The HP Business Intelligence Maturity Model,' Viewed on 21 April 2009. <http://h71028.www7.hp.com/ERC/downlo ads/4AA1-5467ENW.pdf

Hostmann, B. (2007). 'Business Intelligence Scenario,' Paper presented at the Gartner Business Intelligence Summit, London.

IDC (2007). "Top Ranked Business Intelligence Tools Vendors Maintain Positions as Acquisition Activity and SMB Vendors Impact the Market, IDC Reveals," Viewed 03 Jul 2007, $<$ http://www.idc.com/getdoc.jsp?containerId=prUS207 67807>.
Juran, J. M., Gryna, F. M. \& Bingham, R. S. (1974). Quality Control Handbook, 3 edn, McGraw-Hill Book Co, New York, NY.

Kahn, B. K., Strong, D. M. \& Wang, R. Y. (2002). "Information Quality Benchmarks: Product and Service Performance," Communications of the ACM :184-192.

Kašnik, A. (2008). “Odel Optimization Infrastructure," Internal material of ZRSZ, Ljubljana.

Ke, W. \& Kwok, K. W. (2008). “Organizational Culture and Leadership in ERP Implementation," Decision support system : 208-218.

Loshin, D. (2003). Business Intelligence: The Savvy Manager's Guide, Morgan Kaufmann Publishers/Elsevier, Boston.

Lupu, A. R., Bologa, R., Lungu, I. \& Bra, A. (2007). "The Impact of Organization Changes on Business Intelligence Projects," Proceedings of the 7th WSEAS International Conference on Simulation, Modeling and Optimization, Beijing, China, September 1517: 414-418.

Moss, L. \& Hoberman, S. (2004). 'The Importance of Data Modeling as a Foundation for Business Insight,' Teradata.

Moss, L. T. \& Atre, S. (2003). Business Intelligence Roadmap: The Complete Lifecycle for Decision-Support Applications, Addison-Wesley, Boston, MA.

Rajterič, I. H. (2010). "Overview of Business Intelligence Maturity Models," International Journal of Human Science. 15(1): 47-67.

Raskin, M. S. (1994). “The Delphi Study in Field Instruction Revisited: Expert Consensus on Issues and Research Priorities," Journal of Social Work Education : 75-89.

Redman, T. C. (1998). "The Impact of Poor Data Quality on the Typical Enterprise," Communications of the ACM 41(2): 79-82. 
15 Journal of Southeast Asian Research

Richardson, J., Schlegel, K.,Hostmann, B. \& McMurchy, N. (2008). "Magic Quadrant for Business Intelligence Platforms," Gartner.

Sacu, C. \& Spruit, M. (2010). "BIDM: The Business Intelligence Development Model," Proceedings of the 12th International Conference on Enterprise Information Systems, Funchal, Madeira-Portugal.

Simon, R. (2002). Performance Measurement and Control Systems for Implementing Strategy,' Prentice Hall.

Tayi, G. K. \& Ballou, D. P. (1998). "Examining Data Quality," Communications of the ACM. 41(2): 54-57.

Turban, E., Sharda, R., Aronson, J. E., \& King, D. (2011). 'Business Intelligence: A Managerial Approach,' Prentice Hall.

Turban, E., Volonino, L. \& Pollard, C. (2010). Information Technology for Management: Transforming Organization in The Digital Economy, Wiley.

Whitehorn, M. \& Whitehorn, M. (1999). Business Intelligence: The IBM Solution Data warehousing and OLAP, Springer-Verlag, NY.

William, S. \& William, N. (2007). The Profit Impact of Business Intelligence, Morgan Kaufmann Publishers, San Francisco. 